\title{
The Praxis of Redemption: Enrique Dussel's Levinasian-Marxist Theology of Sin and
} Salvation

\section{From Domination to Liberation: An Economy of Salvation}

Enrique Dussel's philosophy in general, and his conception of liberation in particular, are profoundly shaped by three interlocutors: Christian liberation theology, Marxism, and the ethics of Emmanuel Levinas. Dussel employs Levinas's philosophy of exteriority, the ethical relation, and his distinction between ontology and metaphysics to build upon the principles of liberation theology in an effort to formulate a theological critical theory and mode of praxis that can sufficiently describe the present, concrete, global apparatuses of oppression and domination, and to describe the conditions that would make possible the liberation from such a situation of unfreedom.

We can observe an evolution in Dussel's thinking about liberation. In the 1970s, Dussel largely adopts the standpoint of liberation theologians like Gustavo Gutierrez who describe theology as a form of critical theory and concrete praxis, conceived in light of the Christian Gospel, and who describe liberation in terms of a kind of economy of redemption or reconciliation. According to this model, liberation is identified with salvation, while political oppression and economic exploitation are viewed as forms of social sin. As with the Hegelian or existentialist theologians like Karl Barth, sin is conceived as alienation — from oneself, others, and God — and salvation, redemption, reconciliation, or liberation is conceived as an overcoming of this fundamental diremption.

For Gutierrez and Dussel, salvation is "the communion of men with God and the communion of men among themselves;" sin, then, is the estrangement from these forms 
of relation, and therefore manifests itself concretely in all situations of oppression, injustice, and exploitation, situations where humanity has become alienated from its responsibility for the other (Gutierrez 151). Gutierrez writes that "sin is evident in oppressive structures, in the exploitation of man by man, in the domination and slavery of peoples, races, and social classes. Sin appears, therefore, as the fundamental alienation, the root of a situation of injustice and exploitation" (175). Dussel takes liberation theology's Hegelian economy of alienation ( $\sin$ ) and reconciliation (salvation) as a given; he writes, "to say 'no' to my neighbor is the only possible sin, it is the 'sin of the world' or the fundamental sin" (BP 26). Historically and politically, this "has taken the form of a 'no' on the part of the North American centre to the Indian, the African, the Asian and to the worker, the peasant and the outcast. It has been a 'no' to the woman in patriarchal families, and a 'no' to the child in the oppressor's educational system" (BP 26). At its most basic level, liberation is the negation of a negation; that is, liberation overcomes the negation of the just relation to the other (saying 'no' to my neighbor) by affirming a responsible form of sociality (saying 'yes' to the neighbor). It is, then, a praxis of caritas that always already requires the transformation of the concrete, social, political, and economic spheres of humanity. It requires the transformation of the self (consciousness), the structures of society (institutions, law, class), and modes of human sociality (mores).

Such a total transformation, then, requires a Great Refusal akin to that advocated by Marcuse, who Gutierrez sites as a worthy interlocutor for the theological praxis of liberation. He writes that, in the liberation approach, sin is not considered as an individual, private, or merely interior reality — asserted just enough to necessitate a 'spiritual' 
redemption which does not challenge the order in which we live. Sin is regarded as a social historical fact, the absence of brotherhood and love in relationships among men, the breach of friendship with God and with other men, and therefore, an interior personal fracture. (Gutierrez 175)

The praxis of liberation - the concrete work of repairing intersubjective communion and communion with God-is a "subversive praxis" which requires that "we...cease to believe in the system" (BP 27). Insofar as the State, money, the Party, the world-system, the self, etcetera, have become the false gods of the "praxis of oppression," liberation requires a mode of atheism, a total refusal of the idols of the established, alienated society which have, heretofore, constituted domination at the local and global levels. Dussel argues that liberation is not achieved simply by the single individual alone, but is a form of social action that requires solidarity, where those who are not among the dominated "assume within the system the position of the oppressed," where we "immerse [ourselves] in the prison of $\sin$ (the system), but do not obey its rules" (BP 28). Liberation then, is neither an individual experience, nor is it simply the coming to self-consciousness of the oppressed themselves, but is a reconciliation that requires a total refusal and the solidarity of all with the oppressed, and a concrete, active contribution to their liberation. Liberation for Dussel and the liberation theologians means the eradication of all forms and instances of domination, exploitation, and suffering and the re-affirmation of intersubjective communion as well as humanity’s renewed communion with God. For these thinkers, this is a concrete process that unfolds historically and at all levels of human self and other relation. It is at once the creation of a new social order that is meant to embody the Kingdom of Heaven on earth and the creation of a new mode of being, a 
"new humanism, one in which man is defined first of all by his responsibility toward his brothers and toward history" (Gutierrez 34).

Already in his work from the 1970s, Dussel expanded upon these fundamental notions of liberation theology by supplementing them with a Levinasian schematism in order to further liberation theology's endeavor to establish a critical theory and praxis that could describe the means for "genuine and total liberation," as opposed to a narrow vision that limits its possibilities to the political and economic spheres of society. Accordingly, Dussel adopts Levinas's biblical figures of alterity — the stranger/peasant, the orphan, and the widow - to characterize the different levels of observable domination. Just as liberation theology sought to add metaphysical, spiritual, and existential liberation to the secular sense of the term, Dussel adds categories that can account for sexual and pedagogical forms of domination, in addition to the economic and political forms. At the level of political domination, we find situations of class, national, and racial domination, as well as conditions of asymmetrical dependency and development; here it is a form of "brother-to-brother" domination. In addition to this, Dussel describes the level of manwoman domination, that is, the situation in which women (especially the Indian, the African, and the poor woman) are systemically dominated by men. Finally, there is the educational or pedagogical form of domination — the "father-son relation" — "a movement whereby the cultural boundaries of the father, the imperialist or the oligarchy extend so as to embrace the other (the son) within its self" (BP 24). It is here that Dussel most effectively marries the Levinasian concepts of totalization (encompassing both militant imperialism and ontology's domination of thought, which codifies the former) and alterity to liberation theology's praxis of liberation. This approach to fusing the two 
Harvard University

ball@math.harvard.edu

standpoints characterizes his work from the 80 s to the present. In works such as

Philosophy of Liberation, Dussel imports Levinas's conceptual vocabulary and

philosophy of alterity into the praxis of liberation theology. As each approach begins by

affirming the priority of responsibility for the other, or for the poor, the match is a reasonable and productive one.

\section{Dussel's Levinasian Marxism}

Though the humanist and existentialist interpretations of Marx-which have effectively sought to emphasize the trajectory of his thought that reveal a concern for the liberation of humanity at large, of human being — have expanded our notion of his work beyond the confines of a critical economics, the liberation Marx conceived remained couched within the political and economic spheres of society and forms of life. Indeed, Marx was concerned with the liberation and actualization of humanity's innate potentialities, but this liberation is always formulated in the context of labor, class, political power relations, social stratification, and the relations of production. It is the economically oppressed, that class which suffers under alienated labor and who must sell their essence in order to continue to exist — the proletariat — who needs to be liberated. Marx, then, conceives of the poor in this pedestrian, narrow sense of the word. Liberation theologians like Dussel and Gutierrez, however, conceptualize the poor from the perspective of the New Testament beatitudes and the principles of Matthew 25:31-46 which establishes a direct link between intersubjective relations and the relation between 
God and $\operatorname{man}^{1}$ signified by the well-known dictum, "what you do for the least of these you do for me." The poor for Dussel and Gutierrez are a category of people that transcend economic and class-based distinctions. The poor who are to be liberated are not reducible to the proletariat class alone, but are a category that signifies all who are oppressed, exploited, and dominated. Dussel writes, 'the 'poor'...is the other in that he does not share the supreme value of the socio-political system. The 'poor' are just as much a category - they are the oppressed nation, class, person, or woman in that these are outside the structure of the oppressor. In this sense, the 'poor' (in the biblical sense) are not the same as the alienated oppressed living within the system [that is, the proletariat in the 'center'] but they do share many of the characteristics of the poor socially and economically speaking" (BP 27). In this sense, the proletariat of the center may be the oppressor (or contribute to the domination) of the proletariat in the periphery, or even of a member of the peripheral ruling class. Similarly, gender-, racial-, and sexuality-based domination occurs in the center as well as in the periphery, and these subjugated too may be subjects in need of liberation. The set of those who are to be liberated is at once broadened, made more complex, and made to reflect our current understanding of concrete geopolitical relations. In keeping with liberation theology's commitment to a sober and practical understanding of the concrete situations of unfreedom, recourse to

\footnotetext{
1 "Then the King will say to those on his right, "Come, you who are blessed by my Father; take your inheritance, the kingdom prepared for you since the creation of the world. For I was hungry and you gave me something to eat, I was thirsty and you gave me something to drink, I was a stranger and you invited me in, I needed clothes and you clothed me, I was sick and you looked after me, I was in prison and you came to visit me.' Then the righteous will answer him, 'Lord, when did we see you hungry and feed you, or thirsty and give you something to drink? When did we see you a stranger and invite you in, or needing clothes and clothe you? When did we see you sick or in prison and go to visit you?' "The King will reply, 'I tell you the truth, whatever you did for one of the least of these brothers of mine, you did for me."
} 
Harvard University

ball@math.harvard.edu

Marx's now-anachronistic and too-simple dichotomy of class antagonism is no longer a sufficient rendering of the global struggle for liberation. In his trademark synthesis of liberation theology and Levinasian philosophy, Dussel replaces Levinas's 'other' with the category of the 'poor.'

Similarly, Dussel's notion of liberation differs from the emancipation envisioned by Marx insofar they envision the nature and cause of domination a bit differently. Though Dussel's philosophy of liberation is grounded in praxis, its early employment of a Christian-Hegelian notion of the economy of reconciliation (that is, a movement from the negating / alienating force of sin or oppression, to the reconciling unification of liberation) makes it more akin to Hegel's dialectical idealism than to Marx's historical materialism. To be sure, historical and material conditions are of paramount importance to Dussel but he departs from Marx in his conception of the alienation that liberation repairs.

Even at his most humanistic - in the period of the 1844 manuscripts, and in portions of the Grundrisse-Marx attributes the cause of alienation primarily to relations of production rather than to modes of human sociality, to say nothing of the language of sin. In the 1844 manuscripts, alienated labor is a product of an economic structure and mode of production, consumption, and a system of valuation. Humanity's alienation from its essential mode of self-actualization is attributable to material relations of production, not to the breakdown of ethical and responsible human relation. However, in the Grundrisse, Marx's take on the source of humanity's alienation-either the breakdown of personal relationships or the nature of the material relations of production-is less clear. 
On the one hand, Marx clearly opposes the kind of historical determinism that he is so often and erroneously said to have advocated. He writes that

it is...certain that individuals cannot dominate their own social relationships until they have created them. But it is absurd to interpret these purely material relationships as natural relationships, inseparable from the nature of individuality... and inherent in it. These relationships are produced by individuals, produced historically. They belong to a definite phase in the development of the individual. The heterogeneity and independence in which these relations still stand opposed to the individuals, prove only that these individuals are still engaged in the production of the conditions of their social life, rather than that they began that life starting from those conditions. This is the natural and spontaneous interrelationship of individuals inside production relations that are determined and narrowly limited. Universally developed individuals, whose social relationships are subject, as their own communal relationships, to their own collective control, are the product not of nature but of history. (70-71)

Individuals are not simply and passively shaped by their material conditions alone, but dialectically reshape those conditions and therefore alter the nature of their social relations. The mode of human relation, then, is not a product of relations of production alone, but is also shaped my human actions. However, as long as the capitalist modes of relation are in place, they will limit the extent of human liberation. Therefore, the only means to achieve full human liberation is to totally overcome capitalism. To summarize, we asked whether the source or cause of alienation was, for Marx, (1) the failure of individual's to relate to one another morally, or, (2) a by-product of historically 
Harvard University

ball@math.harvard.edu

contingent relations of production. For Marx, both are the cause of alienation. However, alienation manifests primarily in relations of production. For Dussel, on the other hand, alienation manifests elsewhere as well. While one mode of alienation's appearance is as a by-product of relations of production, it is more so a product of a moral failure and therefore manifests in ways beyond those attributable to the sphere of material relations.

Though Dussel will locate a great deal of oppression and exploitation in these determinants, he argues that there are manifold other causes as well, such as - to name only a few - the history of Western colonization, patriarchy, and the domination of thought at the hands of Western ontology, the latter being the pedagogical handmaiden of imperialism. For Marx, domination is ultimately rooted in the structures of exchange and relations of production; for Dussel and the liberation theologians, alienation is rooted in a defective form of human relation and the breakdown of moral sociality, which is manifested in diverse forms of oppression, exploitation, and domination. For Marx, alienation has a material base, for liberation theologians, it is caused by a quality of intersubjective relation, more specifically, by the negation of the other and indifference to the suffering of the 'poor.'

Lastly, though this brief treatment is in no way exhaustive, Dussel's sense of liberation differs from that of Marx's in perhaps the most obvious way: in the former's Christological point of view and explicit profession of faith in Christian revelation. Dussel, however, offers a provocative way in which to bridge this seemingly abysmal distance between their respective stances in regard to liberation and its relation to belief. Once again, he will appeal to Levinas to accomplish this. Here, Dussel makes use of his own version of Levinas's notion of atheism. He argues that, in order to refuse the system 
Harvard University

ball@math.harvard.edu

of oppression which says 'no' to the neighbor, and to begin saying the liberatory 'yes' to the poor "we have...to cease to believe in the system"; therefore, atheism-in regard to an established order that has become fetishized — is a starting point for both Marx and Dussel. He writes, "when Feuerbach and Marx said that they did not believe in the 'god' of Hegel and of the European bourgeoisie (the only god they knew), they set out along the correct and orthodox path" (BP 27). Dussel reads Marx back into Levinas, combining the former's critique of fetishism with the latter's unique sense of atheism in order to develop his own conception of how the periphery's liberation from the center must proceed. We recall that a fetish is "something made by the human hand but made to appear divine, absolute, worthy of worship, fascinating, tremendous, that before which one trembles in fear, terror, or admiration" (PL 96). Moreover, "when a political system attains central power, geopolitically, economically, and militarily speaking” it tends to divinize, fetishize, absolutize, or totalize itself (PL 96). Once the system is divinized, blasphemy becomes unthinkable. It is in this context that Marx's claim that "the beginning of all criticism is the criticism of religion" reveals its full meaning, namely that it is the fetishistic religion of the center, the process in which the system absolutizes itself, that must be denied for liberation to be possible. It is in light of this that Dussel argues that "atheism vis-à-vis the present system is a prerequisite for innovative, procreative, liberative praxis" (PL 96). Authentic atheism then-the denial of the divinity of the fetishized system - is the negative precondition for liberation. He writes, "Marx says that atheism as a pure negation of essentiality no longer makes sense; atheism negates a god (fetish) and affirms, by reason of this negation, the existence of human beings, of the poor, of the oppressed... Such atheisms are a precondition of the possibility 
Harvard University

ball@math.harvard.edu

of liberative revolution" (PL 98). In order to affirm the other, we must first negate the fetishized, divinized system of oppression. The great refusal that leads to the liberating 'yes' to the other begins — for both Marx and Dussel—with "atheistic antifetishism" (PL 97). However, and this is where Dussel and Marx part company, this entails a prior hypothesis. Dussel argues that in order to deny the possible divinity of any system, you must first affirm that "the divine is other than all systems" (PL 98). "Only this affirmation," argues Dussel, "is the condition that makes revolution possible—liberating mobilization against a fetishized system" (PL 98). Further, he claims that the person who "assumes responsibility for the oppressed, in the presence of the absolute other, is a bearer of religion — not fetishized religion but metaphysical religion, the origin of all just systems” (PL 99). Dussel's “necessary hypothesis," the prerequisite of a kind of religious atheism, is a profound departure from Levinas's sense of atheism insofar as, for the former, it is a component for initiating liberation built on a Christian reading of Marx. Methodologically, Dussel's mode of theorizing liberation is close to that of Marx, insofar as critique is the starting point of each thinker. Praxis and a deep commitment to the concrete exigencies, needs, and practical facts for both the interpretation of the present situation and the elaboration of a plan for the active liberation of the poor is also of primary importance for both Dussel and Marx. And finally, history, the historical movement towards liberation, and the contingent historical-material conditions that contextualize and shape the level and quality of liberation is also of vital importance for both thinkers. From its very beginnings, liberation theology has been conceptualized as a form of philosophy that is deeply committed to praxis and service to the poor aimed toward their liberation, and formulated in light of the Christian gospel. These thinkers see 
liberation as inseparable from salvation history, and therefore, the concrete level of liberation is always already read in the context of a historical development of freedomboth existential and social.

\section{From Phenomenology to Praxis: Levinas and Planetary Hamartiology}

Ultimately, Dussel is concerned with the practical demands of Levinas's ethics. While he finds Levinas's purely phenomenological ethics to be incapable of sufficiently ministering to the unique, historically contingent needs of the people, Dussel is certain that the fundamental postulates of the ethics should not only be assumed as the first principles of any valid practical philosophy, but, moreover, that these precepts are consistent with the norms put forward in the New Testament. For Dussel, the epoché alienates Levinas from the actually existing other; therefore his work is largely an attempt to liberate Levinas's ethics from the bracketing that prevents it from developing from a merely critical theory, into a truly emancipatory practical philosophy that advances constructive strategies for instituting justice. Though he considers Levinas's philosophy to be an effective model for the critique of the prevailing social order, he writes that "Levinas fails to present, phenomenologically, the practical construction of the 'new' Totality aimed at the service of the Other, the poor, the widow, the stranger" ("Politics" 87). He places part of the blame for this failure on the limitations of the phenomenological method. He writes, "Phenomenology should be 'mediated' by categories belonging to other epistemic disciplines" ("Politics" 81). And this is precisely what Dussel does, he blends elements of Hegel, Marx, and Levinas with those of 
Harvard University

ball@math.harvard.edu

Christian theology to produce a practical philosophy "aimed at the service of the Other, the poor, the widow, the stranger."

Over the last forty years, Dussel has been a leading proponent of Levinasian ethics, employing and expanding upon Levinas's ideas in evermore profound and admirable ways. But in doing so, Dussel has also charted the limitations of Levinas's work, particularly in the domain of the political. To be sure, Levinas develops an indispensable phenomenology of the ethical relation, one that reveals abstract ethical norms and the fundamental ways in which our subjectivity is conditioned by our encounter with the other. Levinas's ethics is an absolutely essential cornerstone upon which Dussel's entire body of work has been built. However, Dussel writes that, though Levinas "brilliantly describes...the face-to-face position...he does not culminate his discourse"; for Dussel, Levinas's work remains incomplete ("Politics" 80). In Dussel's view, to quote Eduardo Mendieta, "there is no ethics if there is no praxis," and more specifically, no "praxis of liberation" (Mendieta x). Dussel maintains that the concrete and practical is anterior to the abstract and theoretical. The ethical does not appear in mere contemplation, but must be actualized in the experience of actually existing people, here and now. While Levinas's work was intensely influenced by his experiences during WWII, insofar as he largely sought to alienate his work from the vicissitudes of the social-political circumstances of his day, he failed to practically "culminate his [ethical] discourse."

Levinas's aversion to the political is well-known and has been discussed extensively. For Dussel's part, he argues that this aversion results from Levinas's conflation of politics with Totality, with state-led modes of domination and warfare. For 
instance, in Totality and Infinity, we read that politics is "the art of...winning [war] by every means" (qtd. in "Politics" 79). Politics is, therefore, according to Levinas, wholly opposed to the ethical. Dussel writes that "Levinas's criticism of politics as the strategy of the state of war is accurate...However, his critique does not avoid the difficulties involved in reconstructing the positive" and emancipatory sense of politics ("Politics" 80). That is, the political is not merely reducible to the established order's praxis of domination, which negates life and the norms of the ethical. Rather, the political also entails the exterior praxis of liberation that affirms life and the practical demands of Levinasian ethics.

Dussel argues that ethics requires that we not only critique any prevailing order that "entails the production of certain victims"- this would be the negative mode of ethics - but also requires us to concretely engage in a positive process of transformation that will actively work towards the liberation of the people, the satisfaction of their needs, and the creation of authentic community. Dussel writes that, "Levinas remains in the negative critique of politics" but fails to envision the positive construction of something new ("Politics" 88). We read, "Levinas ends with the ethical critique of the Totality, but he cannot think the...construction of a new Totality. It appears that Levinas cannot formulate a positive politics" ("Politics" 88). Dussel maintains that Levinas is "the genius of negativity," and yet, although this " Anti-politics...or deconstructive negativity is fundamental," a positive politics is also necessary, one "oriented to constructive and innovative liberation" ("Politics" 81).

That is, much is said, in Levinas's work, about the call of the voice of the other, but nothing is said about how, concretely, we are to respond to that voice, to that call. 
Levinas holds forth on our foundational responsibility but remains silent about how we are to actualize that obligation. Dussel writes that this inevitably leads us to ask Levinas, "How to feed the hungry, how to do justice to the widow, how to build an economic order for the poor, how to reconstruct the structure of the law in a political order that [is] so inhospitable to the stranger?" ("Politics" 80). Dussel writes that, in Levinas's phenomenology, "the poor pro-vokes, but in the end, he stays poor and miserable forever" ("Politics" 81). Ultimately, Dussel concludes that, "the mere phenomenological categories [of] Levinasian ethics are not sufficient in political or economic philosophy" ("Politics" 84). Therefore, Dussel maintains a commitment to Levinasian ethics, establishing it as the foundation of his own political philosophy, but in order to transcend what he regards as the limitations of Levinas's thinking, he appeals to Marxism and to Christian theology, to create a praxis that uniquely blends these three traditions. Because Levinas's work is strictly "negative," Dussel situates his own critique of the prevailing social order within a Levinasian framework, while also using it as a normative basis for the development of "new Totality," for a more just social order that seeks to liberate those who are poor, in the biblical sense.

Dussel Christianizes the Levinasian ethic by identifying it with norms drawn from the gospels. Moreover, Dussel synthesizes this Christianized Levinas with key features of Marxist thought to develop a remarkably coherent and consistent philosophical system that both offers a critical-explanatory assessment of current geopolitics and proposes a set of positive principles necessary for the establishment and maintenance of a just society. This entire philosophical system is ultimately founded upon the simple paradigm of the face-to-face ethical relation as conceived by Levinas. 
For Dussel, Levinas's face-to-face relation is the ultimate model of agape, of Christian love, as he puts it, "love for the other as other" (Ethics 10). But, this model is still too ideal; for Dussel, the abstract is always inferior to the practical. He writes that, the "face-to-face relationship between two persons is an abstraction"; but in the concrete, agapic face-to-face relationships that actually occur in the real world, "Christian love is lived in the plural, in community, as a people" (Ethics 11). So, Dussel designates the category of "community" to denote a condition where the face-to-face relation is lived socially, "in the plural." He writes that community is "the face-to-face relationship of persons standing in a relationship of justice" (Ethics 16). Moreover, he contends that community, understood in this way, is "the [very] essence of Christian life" (Ethics 16). He continues, "the radical principle of Christian ethics is the face-to-face...relationship in the concrete, real, satisfied, happy, community, in the gladness of being one with God" (Ethics 16). Dussel always reads Levinas's face-to-face relationship through the parable of the "Judgement of the Nations" recorded in the gospel of Matthew, in which we're told that an individual's relationship with God is mediated by their relationship with others, and more specifically, through one's relationship to the poor. In our expression of love for the other, we express our love of God. By the same token, the negation of this relationship, the denial of the other as other, constitutes one's rejection of God.

Ultimately then, for Dussel, Levinas's face-to-face, lived concretely, constitutes the very “essence of Christian life" and is the Christian paradigm for humanity's relationship to God. It is upon this very basic principle that Dussel predicates his entire philosophical system. 
Harvard University

ball@math.harvard.edu

One of Dussel's first steps in building upon this basic premise is to further develop his hamartiology by incorporating Levinas's ethics into the theology of sin he had formulated in line with Marxism and liberation theology earlier in his career. He writes, "evil, wickedness, is the interruption, the breach of this face-to-face," when "one term of the relationship absolutizes itself and negates, annihilates, reifies (makes a thing out of) the other" (Ethics 17). He continues, "evil begins as idolatry, fetishism, atheism; it develops in the domination of human beings by their own brothers and sisters" (Ethics 18). "It is not the person-person relationship that prevails, but the I-thing relationship, the relationship of subject to object. Instead of two 'someones,' we have one 'someone' in confrontation with 'things.' We have 'reification'" (Ethics 18). So, sin is always already a practical relationship, and can only occur in concrete reality, in relation to others; in particular, in relations characterized by "the domination of one human being by another" (Ethics 20, 35). For Dussel, sin just is the breach of the normative face-to-face relation described by Levinas, a breach which simultaneously appears as reification-when the other is not regarded as an autonomous other, but rather as a mere thing — as idolatry, when one absolutizes oneself, or constitutes oneself as the sovereign of the other, in a sense deifying oneself - and as atheism, because, when one negates the other as other, one negates God. Dussel writes, "in negating the other, in negating God, sinners are left to themselves. They totalize themselves, asserting themselves as God, fetishizing and divinizing themselves. They fall into idolatry" (Ethics 19). Again, this is in keeping with the notion that what one does "to the least of these," one does to God. While Christian love and piety are actualized in the ethical face-to-face relation, their antitheses - atheism and idolatry - appear in the social relation of sin, or, in Dussel's language, in the praxis 
Harvard University

ball@math.harvard.edu

of domination, when one refuses to recognize the other as other, and in doing so, rejects

God and deifies oneself. So, in Dussel's work, Christian notions of sin and evil are defined according to concepts characterized by a kind of Levinasian Marxism, where reification and fetishism result from the negation of ethical intersubjectivity. Where Levinas had narrowly regarded politics as synonymous with Totality, Dussel makes a distinction between two different modalities of the political that stand in dialectical opposition to one another; one, being the sinful praxis of domination, in which the faceto-face is rejected, and another, redemptive mode, which he calls the praxis of liberation, which takes the face-to-face relation as its first principle.

Dussel combines elements of Levinasian ethics and Marxism to develop a theory of dialectical salvation history, incorporating key terms drawn Levinas's conceptual lexicon to create a teleological Christian theology. He juxtaposes a large set of conceptual terms in order to map this image of dialectical salvation history, where historically contingent modes of domination are set against modes of liberation, in an ongoing struggle. For example, Totality is in perpetual conflict with Exteriority, the rich with the poor, morality with ethics, center with periphery, Babylon with Jerusalem, society with community, sin with salvation, death with life, etcetera. For Dussel, history is marked by a succession of prevailing moralities, or Totalities, where praxes of domination are fetishized or naturalized and falsely regarded as divinely sanctioned and ontologically necessary. And these consecutive Totalities are perennially critiqued and corrected by prophetic praxes of liberation that are exterior to, or on the periphery of these prevailing moral orders. It is through this continual confrontation of sin and salvation (each of which, we should recall, are concrete forms of intersubjectivity), and through the 
Harvard University

ball@math.harvard.edu

recurrent renunciation and reaffirmation of the face-to-face of love that God appears and is progressively known by humanity throughout the course of history.

In Dussel's work, Totality and Exteriority are the fundamental terms of the dialectic of salvation history. Further synthesizing Levinasian ethics, Marxist dialectics, and Christian theology, Dussel writes that these "two categories [Totality \& Exteriority]...make up the main focus of the whole ethical discourse of the prophets, of Jesus, and of the martyrs" (Ethics 48). By Exteriority, Dussel means that which stands "in dialectical opposition to the prevailing order of the established system," that is, in opposition to Totality and $\sin (51)$. Exteriority is utopian, insofar as it has no-place, and stands entirely outside of Totality; it is, as he puts it, "the horizon that criticizes the injustice [of the] dominant order. It tells us, 'This is not good enough!'” (Ethics 38, 16). This Exteriority, which Dussel identifies with the ethical norms advocated and put into practice by the prophets, Jesus, and the martyrs, is in a continual process of correcting and modifying Totality from the outside. But, even when this kind of prophetic direct action succeeds in creating new a order, one that is more consonant with ChristianLevinasian ethical norms, this new order is inevitably transformed once again into, as Dussel puts it, a "“moral' order that legitimates sin." That is, exteriority's negation of totality, is itself negated, ad infinitum; both the failures and the triumphs of the ethical are necessary elements of salvation history, the process by which God is progressively made known to humanity. Dussel writes, "liberation starts with the slavery of Egypt...and ends in the construction of Jerusalem. But, when the dreamed 'new' Jerusalem is finally built, it slowly transforms itself into Egypt, the 'second' Jerusalem, the Jerusalem to be 
deconstructed, and this history will continue, never repeating and always renewing itself, as the history of the politics of liberation" ("Politics" 88).

Perhaps a more concrete example of this dialectical schema of salvation history can be found in Dussel's analysis of current institutions, and their progressive ethical degradation, or what he calls "the entropy of institutions" ("Politics" 91). He argues that institutions begin by responding well to the needs of the people, and after a "classical" period of equilibrium, in which those needs continue to be adequately met, they enter of period of crisis, when their practices cease to be consistent with ethical norms.

Institutions that begin by operating according to a praxis of liberation inevitably devolve, becoming corrupt and exploitative. He writes that "a new Totality [or a new institution]...will [necessarily] become the old Totality" ("Politics" 88). That is, "institutions always become, with time, totalized mediations with the potential to 'kill'" ("Politics" 89). He continues, "there always arises a moment in which [institutions] need to be transformed...or destroyed," and it's in this "moment of...totalization," that Exteriority “awakens again" to criticize injustice ("Politics" 91). This diremptive moment, this moment of negation, is a function of what Dussel calls the ambiguity of power. In the process of attempting to meet the needs of the people in the context of complex systems of social organization, the institutionalized exercise of the people's power can go one of two ways: it can take the form of, what he calls "obediential power," in which the people's delegates in government, for example, command through obedience to the will of the people. In this case, government maintains its fidelity to the ethical, by institutionalizing responsibility. But, on the other hand, institutionalized power can become fetishized. In this case, a reifying inversion takes place, where the people are 
required to serve the self-interest of their delegate or the interests of their delegate's party, rather than the representative serving the needs of the people. This is just one example where Dussel appeals to Levinas's normative notions of responsibility and privileging the needs of the other to determine the legitimacy of large-scale modes of governance, as opposed to allowing this standard to remain inert in an epoché that merely considers the abstract relation of single individuals. In light of this inevitable negation of the ethical in our institutions, and in direct opposition to Levinas, Dussel writes, "this ambiguity [of power...this will-to-totalization] does not divest politics of its necessity or its sanctity as service to the Other" ("Politics" 89). Dussel takes this position, again, because he regards this process of institutional correction and transgression as an essential feature of salvation history, of the way in which God makes Himself known to humanity.

Understanding this dialectical conception of salvation history gives us a better sense of what exactly Dussel and other liberation theologians mean when they refer to the poor. Dussel explains that, in this perspective, "poor and rich...are dialectical categories," (Ethics 23). He writes, “"poor,' in the biblical sense, denotes the dominated, oppressed, humiliated, instrumentalized term of the practical relationship called sin. The constitutive act of the 'poor'...is not lacking goods, but being dominated...by the sinner," or the 'rich' (Ethics 22). So, the poverty of the poor is not a function of material privation or the lack of goods, but is the result of being dominated and dispossessed. For this reason, the category of the poor is not limited, for example, to an industrial working-class, or to the peasantry, but, more broadly, refers to those manifold groups who have suffered systematic domination over the course of history. The poor, then, in this dialectical, 
Harvard University

ball@math.harvard.edu

biblical sense, refers equally to the Jews under the reign of Pharaoh, as well as to contemporary victims of institutionalized racism, homophobia, sexism, to the colonized, and even to citizens of a nation that is systematically exploited by a global metropolis like Rome, Spain, Britain, or the United States, including that nation's bourgeoisie. Dussel's methodology is, as he puts it, to "ascend...from the simple to the complex, from the abstract to the concrete" (Theses 71). Dussel uses Levinas's simple one-to-one ethical relation as the criteria by which to assess the legitimacy of complex relations of power, and in doing so, develops a robust reading of geopolitics, and ultimately a kind of planetary hamartiology. This Levinasian theology of sin furnishes Dussel with a formal model, but one that must be accompanied by the concrete economic, historical, and cultural content that will make his own practical philosophy more relevant and constructive than Levinas's pure theory. Ascending from the simple to the complex, Dussel moves from the one-to-one relation of transcendental subjects, first, to consider the actually existing relations that pertain among groups, such as those of community and state, those among classes, among parties, races, ethnicities, genders, and sexualities. Ascending even further from the face-to-face, Dussel considers the relation of nation-tonation, and even that of Continent-to-Continent, that of Center to Periphery, colonizer to colonized, of so-called first to third worlds, these categories being analogous to those of Totality and Exteriority. By doing this, Dussel prophetically exposes global structures of sin. In our time, the polis has become global, and, therefore, the horizon of prophetic discourse must extend accordingly. Dussel argues that, today, the modes of domination that existed between Cain and Abel, Egypt and Israel, or between the bourgeoisie and the proletariat, are subordinate to the sinful social relations that prevail between developed 
Harvard University

ball@math.harvard.edu

and underdeveloped nations, between the IMF and the global south, between multinational conglomerations of power and a diverse social bloc of the oppressed.

With this in mind, Dussel promotes a kind of Pauline, ecumenical inclusivity among the world's victims. Whether one is a Jew or a gentile, bourgeois or proletarian, indigenous or non-native, all those who suffer domination share a common fraternity. A recognition of this shared condition, he believes, can repair the alienation of these divergent groups of victims, allowing us to transcend, as he puts it, "differential particularities" to form a "universal hegemonic claim;" that is, his planetary hamartiology aims to both critique globalized structures of sin, and to advocate a form of solidarity among the world's poor that will enable a more communal demand for the redemption of those sins. By fully incorporating the concrete conditions of the world's poor into his theology of liberation, and by founding that theology on a conception of $\sin$ that unifies seemingly diverse groups of marginalized people, Dussel is able to formulate emancipatory strategies that move beyond Hegel's idolatry of the state, Marx's classbased radicalism, and beyond the sectarianism of identity politics. For Dussel, this kind of planetary propheticism, which takes a Christianized Levinas as its starting point, is simply the next, necessary phase in the progression of salvation history.

Dussel finds in Levinas's work principles that can guide an ethical critique of existing conditions but not principles that can adequately guide ethical action, so he sees himself as completing a project begun by Levinas, or at least as significantly building upon that project. So, if Dussel only finds in Levinas's work a negative, critical philosophy, then what kind of positive principles does he contribute? We know that he advocates a "praxis of liberation," but just what does that look like? He argues that an 
Harvard University

ball@math.harvard.edu

important place to begin is by actively working to transform existing institutions. We recall that he regards salvation history as being constituted by the conflict of Totality and Exteriority, a process which continues to produce new, ever more just, Totalities, Totalities which will themselves be superseded. So, we apply a Levinasian rubric to discern the unjust or sinful aspects of existing institutions and take action, in conformity with our ethical norms, to correct those errors, thus, as Dussel puts it, "introduc[ing] innovation into actions...to create history anew." He argues that our creative efforts to engender a new Totality are guided by three positive demands: what he calls the material principle, the legitimacy principle, and the feasibility principle. Dussel offers a comprehensive exposition of these demands in his two, large, systemic works, Ethics of Liberation in the Age of Globalization and Exclusion and in his three-volume work, yet to be translated into English, The Politics of Liberation. His brief text, Twenty Theses on Politics, is a kind of microcosm of this latter work. Though I cannot rigorously analyze each of these principles here, it is worth remarking briefly, by way of conclusion, on the material principle.

With a suggestion of the incarnational, Dussel contends that the other is always already an embodied, fleshly other. Our most fundamental imperative then, is to secure conditions for the survival and preservation of the living corporeality of the other. Ethical praxis then, must be rooted in a theology of need. He writes that, "the ethical is...governed by...what the poor require, by the needs of the poor oppressed by the struggle with domination." Such historically contingent needs cannot be assessed phenomenologically, hence, once again, the need for a philosophy that is cognizant of the concrete circumstances of sin. Dussel's theology of need subtly problematizes the "Need 
and Corporeity" section of Totality and Infinity, where Levinas pejoratively identifies need with 'the same,' as opposed to metaphysical desire which is associated with the other. With this emphasis on the material principle, on the obligation to actively fortify the life of the other, to "attempt through all means to allow all to live, to live well, and to increase the quality of their lives," Dussel effects a subtle, but highly significant shift from Levinas's well known appeal to the prohibitive commandment, "Thall Shall Not Kill," to the imperative, "Feed the Hungry!" For Dussel, hunger in both the literal and conceptual sense, is the fruit of sin, of the negation of the face-to-face of love. Therefore redemption requires the satisfaction of that essential need. By comparing these two fundamental demands_ — "Thall Shall Not Kill" and "Feed the Hungry!"- - we can see what Dussel finds to be so insufficient in Levinas. Yes, we must refrain from killing the other, but that is not where our responsibility ends, we must go even further, to actively affirm and enrich the lives of our neighbors. The former is a negative norm, that which we must not do, whereas the latter is a positive norm which directs our action towards what we must do. For Dussel, it is on the basis of these positive demands, on the material, legitimacy, and feasibility principles, and from the standpoint of Exteriority, that we actively create a new Totality and thus initiate the next phase of salvation history. 
Harvard University

ball@math.harvard.edu

\section{Works Cited}

Dussel, Enrique. Beyond Philosophy: Ethics, History, Marxism, and Liberation Theology.

Ed. and Trans. Eduardo Mendieta. Lanham: Rowan and Littlefield, 2003.

Ethics of Liberation: In the Age of Globalization and Exclusion. Durham:

Duke UP, 2013.

. Philosophy of Liberation. Trans. by Aquilina Martinez and Christine

Morkovsky. Maryknoll: Orbis Books, 1985.

_."The Politics' by Levinas: Toward a 'Critical' Political Philosophy,” in

Difficult Justice: Commentaries on Levinas and Politics. Eds. Asher Horowitz

and Gad Horowitz. Toronto: University of Toronto Press, 2006.

. Twenty Theses on Politics. Trans. by George Ciccariello-Maher.

Durham: Duke UP, 2008.

Gutierrez, Gustavo. A Theology of Liberation: History, Politics, and Salvation. Ed. and Trans. Sister Caridad Inda and John Eagleson. Maryknoll: Orbis Books, 1973.

Marx, Karl. The Grundrisse. Ed. and Trans. David McLellan. New York: Harper and Row, 1971.

Mendieta, Eduardo. "The Liberation of Politics: Alterity, Solidarity, Liberation," in Twenty Theses on Politics. Trans. by George Ciccariello-Maher. Durham: Duke UP, 2008. 